\title{
Metabolic Control
}

National Cancer Institute

\section{Source}

National Cancer Institute. Metabolic Control. NCI Thesaurus. Code C19344.

Regulation of metabolic pathways 